\title{
Influence of organic manure amendments on water repellency, water entry value, and water retention of soil samples from a tropical Ultisol
}

\author{
T.D.P. Liyanage, D.A.L. Leelamanie* \\ Department of Soil Science, Faculty of Agriculture, University of Ruhuna, Mapalana, Kamburupitiya 81100, Sri Lanka. \\ ${ }^{*}$ Corresponding author. Tel.: +94-71-861-4380. Fax: +94-41-2292384. E-mail: leelamanie@soil.ruh.ac.lk, leelamaniee@yahoo.co.uk
}

\begin{abstract}
Lowered stability of soil aggregates governed by insufficient organic matter levels has become a major concern in Sri Lanka. Although the use of organic manure with water repellent properties lowers the wetting rates and improves the stability of soil aggregates, its effects on soil hydrophysical properties are still not characterized. Therefore, the objective of this study was to examine the relation of water repellency induced by organic manure amendments to the water entry value and water retention of a Sri Lankan Ultisol. The soil was mixed with ground powders of cattle manure (CM), goat manure (GM), Gliricidia maculata (GL) and hydrophobic Casuarina equisetifolia (CE) leaves to obtain samples ranging from non-repellent to extremely water repellent, in two series. Series I was prepared by mixing GL and CE with soil $(5,10,25,50 \%)$. Series II consisted of $5 \% \mathrm{CM}$, GM, and GL, with (set A) and without (set B) intermixed $2 \% \mathrm{CE}$. Water repellency, water entry value, and water retention of samples were determined in the laboratory. Soilwater contact angle increased with increasing organic matter content in all the samples showing positive linear correlations. Although the samples amended with CE showed high soil-water contact angles in series I, set A (without $2 \% \mathrm{CE}$ ) and set $\mathrm{B}$ (with $2 \% \mathrm{CE}$ ) in series II did not show a noticeable difference, where $>80 \%$ of the samples had soilwater contact angles $<90^{\circ}$. Water entry value $\left(\mathrm{R}^{2}=0.83-0.92\right)$ and the water retention at $150 \mathrm{~cm}$ suction $\left(\mathrm{R}^{2}=0.69-0.8\right)$ of all the samples increased with increasing soil-water contact angles showing moderate to strong positive linear correlations. However, set A (without 2\% CE) and set B (with 2\% CE) in series II did not differ noticeably. Water entry value of about $60 \%$ the samples was $<2.5 \mathrm{~cm}$. Mixing of a small amount $(2 \%)$ of hydrophobic organic matter with commonly used organic manures slightly increased the water repellency of sample soils, however not up to detrimental levels. It did not generate adverse effects on water entry and increased the water retention. It was clear that intermixing of small quantities of hydrophobic organic manure with organic manures commonly used in Sri Lankan agriculture, would not generate unfavorable impacts on soils.
\end{abstract}

Keywords: Hydrophysical properties; Organic manure; Water entry value; Water repellency; Water retention.

\section{INTRODUCTION}

Water repellency of soil restricts the spontaneous wetting and forms water beads when water is placed on the soil surface. The wettability of a soil surface is governed by the molecular attractions at the soil-water interface. In readily wettable soils, the attraction between soil and water molecules is more prominent and stronger than the attraction between molecules of water. On hydrophobic soil surfaces, the attraction between water molecules is stronger than the attraction between soil and water molecules making water bead-up on the surfaces (DeBano, 1981; Leelamanie and Karube, 2013). Water repellency in soils might restrict wetting of soils for periods of few seconds to hours, days, or weeks (Maia et al., 2011) depending on its strength.

Water repellency is caused by either the intermixed hydrophobic organic substances or hydrophobic organic coatings formed on the mineral soil particles (DeBano, 1981; Hallett, 2007; Leelamanie, 2016). In general, mineral soils have high surface free energy compared with organic materials, and therefore, are hydrophilic. Intermixing or coating with low energy organic matter can suppress the hydrophilic nature of mineral soils to make them water repellent (Qu et al., 1994) by increasing the either proportion of intermixed organic fractions or the coverage of mineral surfaces with organic coatings (Chenu et al., 2000). The organic compounds that are responsible for developing soil water repellency are found to be plant roots and microbial exudates, surface waxes of leaves, and other hydro- phobic organic substances with long chain aliphatic acids, alcohols, wax esters, etc. (Bisdom et al., 1993).

Water repellency is reported to cause reduced rates and uneven patterns of water infiltration into soils creating unstable water flow within the soil matrix (de Jonge et al., 1999; Rodny et al., 2015), and affecting almost all of the hydrophysical properties and processes of soils including sorptivity and hydraulic conductivity. It influences hydrophysical parameters and water flow in the soils through phenomena such as bio crust formation (Lichner et al., 2012), and increases runoff rates. The inherent water repellent characteristics of soils under different types of vegetation can also persuade soil hydrological processes, especially after longer hot or dry weather conditions (Lichner et al., 2010). Increase in surface runoff and overland flow play an important role in intensifying soil erosion (Doerr et al., 2000; Goebel et al., 2004a; Pires et al., 2006). Localized high and less water repellent areas in these soils allow the selective water entry through less water repellent patches, stimulating preferential flow paths. Preferential flow moves rapidly through the soils bypassing the complete wetting of soil matrix causing the leaching of nutrients and agrochemicals, subsequently enhancing contaminant transport to induce groundwater contamination (Bauters et al., 2000; Hallett, 2007; Kodesova et al., 2015). Decreased availability of soil moisture in the rhizosphere may suppress the emergence and survival of seedlings as well (Madsen et al., 2012). The characteristic patchiness related with uneven moisture distribution within the soil profiles of water repellent soils also creates problems when using these soils for crop production (Ward et al., 2015). 
Water entry value and water retention are two of the characteristics that are considered to be of prime importance for the plant growth. The water entry value means the critical pressure which is required for forcing water to enter into the soil. At this pressure, water starts to infiltrate into the soil causing instantaneous breakdown of repellency in water repellent soils (Wang et al., 2000). Water entry value is considered to be a function of soil hydrophobicity and pore size distribution in soil. It is used in numerous simulation models to predict infiltration, water flow stability, and speed of fingered flow in the field (Letey et al., 2000; Morel-Seytoux and Khanji, 1974). The water entry values of water repellent soils are usually thought to be positive because of the requirement of high hydraulic pressure to breakdown the repellent nature for water to enter into the soil (Karunarathna et al., 2010). The ponding depth of water should be equal or higher than the water entry value for water to infiltrate into the soil, where at lower ponding depths, the water infiltration is retarded increasing the surface runoff. This predicts high potentials for increased surface runoff and erosion in soils with high water entry values (Wang et al., 2000).

The water entered into the soil matrix flows through the pore spaces between the soil particles and the excess water is drained from the soil under the force of gravity. The rest of the water that retains in the soil after drainage, or the retained water, is available for plants to uptake (Gardner, 1979). Soil water retention defines the water content that can be retained in soil as a function of suction or the water potential in the soil pore spaces (Vanapalli et al., 1999) and gives an idea about the water holding capacity of the soil. It can be used as a basis for the prediction of other unsaturated soil parameters such as permeability (Fredlund and Xing, 1994). Soil water retention can be linked with vast areas of hydrology, agronomy, meteorology, ecology, environmental protection, and many other fields related with soils (Rawls et al., 2003). Water retention capacity in soil profile is reported to be sensitive to the differences in organic matter contents (Viville et al., 1986), especially in soils with organic matter contents beyond 5\% (McBride and MacIntosh, 1984). The structural changes of soils which are especially determined by humus content and soil quality greatly influence the pore size distribution and water retention of soils (Rajkai et al., 2015). Furthermore, water retention of soil is believed to be dependent on the degree of hydrophobic nature in soils (Diamantopoulos et al., 2013).

With the development of organic farming as a concept of sustainable agriculture, use of organic manure has extensively been spread among farming communities (Hole et al., 2005). Depletion of soil organic matter due to rapid decomposition rates is considered to be one of the major reasons for the declined fertility in soils in Sri Lanka. Use of organic manure is considered to be one of the most important techniques to increase and maintain soil fertility since ancient times. Organic manures in the form of animal manure, green manure, and compost has long been used for agriculture in Sri Lanka, although their effects on water repellent nature or the hydrophysical parameters of the soils have not been taken into consideration.

Declined soil organic carbon pool as a result of the changes in land use is reported to lower the stability of aggregates in Sri Lankan soils (Leelamanie and Mapa, 2015). Furthermore, application of commonly used organic manure in Sri Lankan soils is found to cause slight reductions in wetting rates, consequently improving the stability of soil aggregates through the strengthened cohesion with respect to the increasing organic matter content (Leelamanie et al., 2013). Still, applications under field conditions faces problems due to the uncertainties and suspicions related with well-known negative impacts of water repellent conditions on soil hydrophysical properties. Therefore, it is necessary to find the possibility of significant developments of any unfavorable impacts on hydraulic characteristics of soils that might be associated with induced water repellent conditions through the amended organic manure. Clarifications are necessary under controlled conditions before experimenting under actual field conditions. The objective of this study was to examine the relation of water repellency caused by organic manure amendments on water entry value and water retention of soil samples prepared from an Ultisol in Sri Lanka, under laboratory conditions.

\section{MATERIALS AND METHODS}

The soil used in the study was collected from the Research and Training Facility of the Faculty of Agriculture, University of Ruhuna, Sri Lanka. The soil is locally known to be redyellow podzolic and falls under Rhodudults according to the USDA soil classification system (Soil Survey Staff, 2014). The area is in the low country wet zone (WL2) agro ecological region $\left(6^{\circ} 06^{\prime} 21^{\prime \prime} \mathrm{N}, 80^{\circ} 54^{\prime} 19^{\prime \prime} \mathrm{E}\right)$. The mean air temperature is fairly uniform at $28^{\circ} \mathrm{C}$ throughout the year. The average relative humidity is around $75 \%$, which is low during February and March. Annual pan evaporation is about $1560 \mathrm{~mm}$ and the mean annual rainfall is about $2350 \mathrm{~mm}$ (Weerasinghe, 1989).

The soil was thoroughly air dried and sieved through a $2 \mathrm{~mm}$ sieve to remove gravel and other non-soil materials. The basic properties of the soil were determined using standard laboratory procedures given in Table 1.

Both animal and green manures were used as the organic manure amendments. Cattle manure (CM) and goat manure (GM) were used as the animal manures and Gliricidia maculata (GL) and Casuarina equisetifolia (CE) leaves were used as the green manures. The CM, GM, and GL are commonly used as organic manures in Sri Lanka, whereas the CE leaves were used as a hydrophobic organic material (Leelamanie, 2014). All the manures were thoroughly air-dried, ground into fine powders using a mechanical grinder, and passed through a $0.5 \mathrm{~mm}$ sieve to remove coarser materials.

The prepared organic powders and the soil were mixed in different ratios to obtain samples ranging from non-repellent to extremely water repellent, in two series. In the first series (series I), the soil was amended with GL and CE at rates of 5, 10, 25 and $50 \%$ (dry weight basis) to compare the effects of hydrophobic and hydrophilic organic manure. The second series (series II) consisted of two sets. In the first set (set A), the soil was amended with CM, GM, and GL at a rate of $5 \%$ to obtain samples with field manure application levels. The second set (set B) was prepared by mixing soils with $2 \%$ of CE and $5 \%$ of CM, GM, and GL to examine the impacts of slight hydrophobicity induced by the $2 \% \mathrm{CE}$, which is found to improve the stability of soil aggregates (Leelamanie et al., 2013), on water entry value and water retention of the soils.

The water entry values of the samples were tested using the pressure head method. Initially, a low negative pressure of -10 $\mathrm{cm}$ was applied to prevent the initial wetting of the soils for 5 minutes and then the pressure was increased up to a point where the water starts to enter into the soil matrix. At the point of water entry, the pressure head was measured as the water entry values of the samples (Wang et al., 2000).

Water retention was tested using suction head method (Croney and Coleman, 1954). A known mass of dry soil was placed on the porous plate of a Buchner funnel connected to a burette by flexible tubing (Figure 1) and saturated (Webb et al., 2014). The porous plate of the funnel was covered with a filter 
Table 1. Basic properties of the soil.

\begin{tabular}{|c|c|c|c|}
\hline Property & Value & Method & Reference \\
\hline Bulk density $\left(\mathrm{gcm}^{-3}\right)$ & 1.46 & Undisturbed core method & Blake and Hartge, 1986 \\
\hline Particle density $\left(\mathrm{gcm}^{-3}\right)$ & 2.68 & Pycnometer method & Skopp, 2002 \\
\hline Porosity (\%) & 45.52 & Numerical method & Redding and Devito, 2006 \\
\hline Texture & $\begin{array}{l}\text { Loamy } \\
\text { sand }\end{array}$ & Hydrometer method & $\begin{array}{l}\text { Bouyoucos 1962; Gee and } \\
\text { Bauder, } 1986\end{array}$ \\
\hline Sand $(\%)$ & 86.0 & & \\
\hline Silt (\%) & 10.9 & & \\
\hline Clay $(\%)$ & 3.1 & & \\
\hline Organic matter content $(\%)$ & 3.27 & Loss on ignition method & Rowell and Coetzee, 2003 \\
\hline $\mathrm{pH}$ & 5.88 & HachsensION $1 \mathrm{pH}$ meter & \\
\hline Electrical Conductivity $\left(\mathrm{mS} \mathrm{m}^{-1}\right)$ & 0.02 & $\begin{array}{l}\text { Hanna Instruments, HI 9812, a.k.a } \\
\text { Combo } 1 \text { EC meter }\end{array}$ & \\
\hline Contact angle $\left({ }^{\circ}\right)$ & 43.4 & Sessile drop contact angle method & Bachmann et al., 2000 \\
\hline $\begin{array}{l}\text { Volumetric water content at } \\
150 \mathrm{~cm} \text { suction }\left(\mathrm{cm}^{3} \mathrm{~cm}^{-3}\right)\end{array}$ & 0.131 & Suction head method & Ouyang et al., 2013 \\
\hline
\end{tabular}

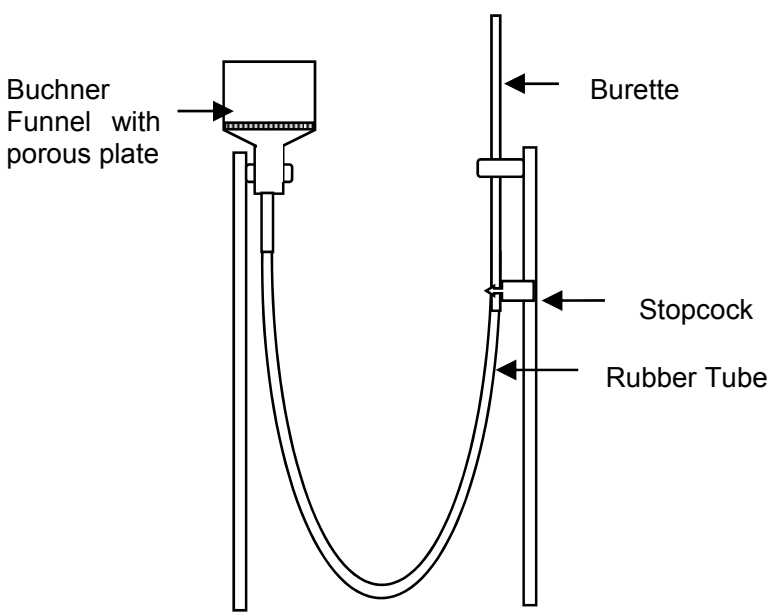

Fig. 1. Apparatus used for the pressure head and suction head experiments.

paper prior to placing the samples to avoid dissolution of fine clay particles with the water. Suction was applied to the sample by lowering the burette level, allowing the suction force to draw water from the soil sample into the burette, and the increased volume of water in the burette and the actual suction height was recorded after 5 minutes. The procedure was repeated with increased suctions and the soil water content was gravimetrically determined at the highest applicable suction (Ouyang et al., 2013). The bulk density of the soil samples used in Buchner funnel and the moisture content at $150 \mathrm{~cm}$ suction are shown in the Table 2.

The water repellency of the soil samples were measured using the sessile drop contact angle method (Bachmann et al., 2000). A glass slide with a monolayer of each sample was placed on the stage of a digital microscopic camera (FKFINESCOPE FS-3100-PC, Fujikoden Co. Ltd., Japan) and a 10 $\mu \mathrm{L}$ drop of deionized water was placed on each surface using a micropipette. A digital microphotograph of the water drop was taken within $1 \mathrm{~s}$ and the contact angles were measured considering the both three phase (soil-water-air) contact points in the microphotograph (Leelamanie et al., 2008).
Table 2. Bulk density and the moisture content of the samples.

\begin{tabular}{lcc}
\hline & $\begin{array}{c}\text { Bulk Density } \\
\left(\mathrm{g} \mathrm{cm}^{-3}\right)\end{array}$ & $\begin{array}{c}\text { Moisture content ant } 150 \mathrm{~cm} \\
\text { suction }\left(\mathrm{g} 100 \mathrm{~g}^{-1}\right)\end{array}$ \\
\hline Soil & $1.02 \pm 0.018$ & $22.07 \pm 7.12$ \\
Series I & & \\
$5 \% \mathrm{GL}$ & $0.89 \pm 0.01$ & $26.75 \pm 2.47$ \\
$10 \% \mathrm{GL}$ & $0.7 \pm 0.023$ & $30.34 \pm 1.54$ \\
$25 \% \mathrm{GL}$ & $0.5 \pm 0.016$ & $42.08 \pm 3.14$ \\
$50 \% \mathrm{GL}$ & $0.3 \pm 0.02$ & $43.49 \pm 0.14$ \\
$5 \% \mathrm{CE}$ & $0.93 \pm 0.03$ & $36.76 \pm 2.48$ \\
$10 \% \mathrm{CE}$ & $0.78 \pm 0.02$ & $36.85 \pm 4.85$ \\
$25 \% \mathrm{CE}$ & $0.49 \pm 0.03$ & $49.16 \pm 4.24$ \\
$50 \% \mathrm{CE}$ & $0.34 \pm 0.01$ & $53.62 \pm 0.83$ \\
Series II & & \\
$5 \% \mathrm{GL}$ & $0.83 \pm 0.034$ & $33.21 \pm 5.96$ \\
$5 \% \mathrm{CM}$ & $0.9 \pm 0.02$ & $25.89 \pm 1.75$ \\
$5 \% \mathrm{GM}$ & $0.89 \pm 0.01$ & $27.92 \pm 7.18$ \\
$5 \% \mathrm{GL}+2 \% \mathrm{CE}$ & $0.84 \pm 0.01$ & $35 \pm 9.22$ \\
$5 \% \mathrm{CM}+2 \% \mathrm{CE}$ & $0.78 \pm 0.01$ & $31.42 \pm 2.72$ \\
$5 \% \mathrm{GM}+2 \% \mathrm{CE}$ & $0.8 \pm 0.006$ & $31.32 \pm 3.38$ \\
\hline
\end{tabular}

All the experiments were conducted at laboratory conditions with $28 \pm 1^{\circ} \mathrm{C}$ and $75 \pm 5 \%$ relative humidity. The data were statistically analyzed with analysis of variance and correlation at 0.05 probability level.

\section{RESULTS AND DISCUSSION}

Figure 2 presents the relationship between organic matter content and the soil-water contact angle of samples amended with CE and GL in different percentages (series I) (Figure 2a), and samples amended with 5\% organic manure with and without addition of $2 \% \mathrm{CE}$ (series II) (Figure 2b), including the control (mineral soil). The soil-water contact angle increased with increasing organic matter content in all the samples. The soil-water contact angles of series I increased with increasing organic matter content showing strong positive linear correlations $\left(\mathrm{R}^{2}=0.93\right.$ and 0.71 , for CE and GL, respectively) (Figure 2a). Compared with the soils amended with GL, those amended with CE showed higher soil-water contact angles at the same 

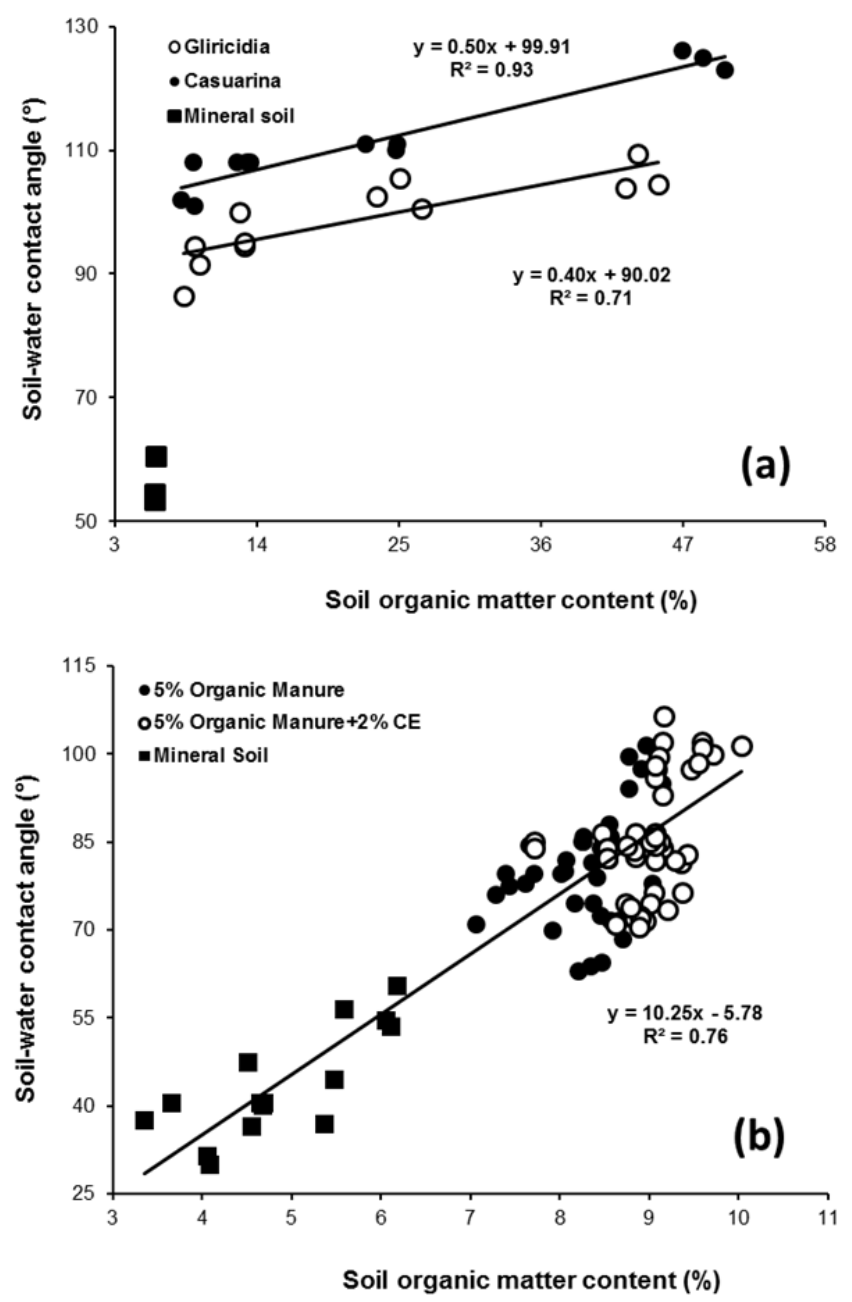

Fig. 2. Relationship between organic matter content and the soilwater contact angle of samples amended with (a) CE ( STD $_{\mathrm{S}}: 1.23$, $\left.\mathrm{STD}_{\mathrm{I}}: 0.04\right)$ and GL $\left(\mathrm{STD}_{\mathrm{S}}: 2.13, \mathrm{STD}_{\mathrm{I}}: 0.08\right)$ (Series I); (b) 5\% organic manure, with and without intermixed $2 \%$ CE $\left(\right.$ STD $_{\mathrm{S}}: 4.89$, $\mathrm{STD}_{\mathrm{I}}$ : 0.59) (Series II). STD : standard error of slope; $\mathrm{STD}_{\mathrm{I}}$ : standard error of intercept.

contents of organic matter. The CE used in this study is reported to show extremely high original hydrophobicity (Leelamanie, 2014), while GL is reported to show hydrophilicity due to the presence of high amount of hydrophilic compounds in the flour protein (Aye and Adegun, 2013). Therefore, the organic material with high amount of hydrophobic compounds initiated higher soil-water contact angles in amended soils compared with organic additives exhibiting a more hydrophilic character.

However, the relation of organic manure content to the soilwater contact angle of soils amended with $5 \%$ organic manure (series II) $\left(\mathrm{R}^{2}=0.76\right)$ did not show a noticeable difference between those with (set B) and without (set A) intermixed $2 \%$ CE (Figure $1 \mathrm{~b}$ ). In both sets, more than $80 \%$ of the samples had soil-water contact angles less than $90^{\circ}$, where the mean contact angles of the two sets (Set A: $80.11^{\circ}$ Set B: $85.57^{\circ}$ ) were not statistically different at the 0.05 probability level. The results revealed that addition of small amounts $(2 \%)$ of highly hydrophobic CE did not increase soil- water contact angle of the samples to create outliers in the relation of organic matter content to the contact angle.

We observed a slight difference in soil-water contact angles between $5 \%$ GL amended soils samples in the series I and series II at nearly the same organic matter contents. Careful examination of gathered data showed that the difference in the two samples was in the air-dried moisture content which can be related to the slight difference in relative humidity during the measurements. The sample with higher moisture content was found to show higher contact angles. Soil-water contact angle is reported to increase with increasing relative humidity (Goebel et al., 2004b; Leelamanie et al., 2008), which might possibly be caused by several processes on the solid surfaces after water vapor adsorption (Goebel et al., 2004b; Good, 1992; Leelamanie et al., 2008; Vogler, 1998). Although GL is hydrophilic, its $(100 \%$ GL) surface free energy was calculated to be around $65 \mathrm{mN} \mathrm{m}^{-1}$, which is lower than that of water $\left(72 \mathrm{mN} \mathrm{m}^{-1}\right)$. The similar circumstance might have caused the higher contact angle at higher moisture content of samples amended with 5\% GL in series I and II.

Effects of intermixed hydrophobic material on entering of water into the soil and retaining of water were studied with water entry value and water retention data. As shown in Figure 3 , the water entry value of all the samples increased with increasing soil-water contact angles showing strong positive linear correlations $\left(\mathrm{R}^{2}=0.83-0.92\right)$. The increasing hydrophobicity of soil organic matter can increase the air encapsulation within the soil during the uptake of water, which is known to reduce the rates of water uptake by increasing the pressure required for the water entry (Sullivan, 2006). This process can be considered as one important reason for increase of the water entry values with increasing water repellency of samples. The samples amended with GL showed negative water entry values at low soil-water contact angles, which is reported to be a phenomenon occur in readily wettable soils (Wang et al., 2000). Accordingly, the samples amended with CE did not indicate negative water entry values as the soil-water contact angles at the least amending rate (2\%) was high enough to eliminate readily wettable behavior from the amended soils. As shown in Figure 3a (series I), water entry values of samples amended with hydrophobic $\mathrm{CE}$ at different rates showed higher sensitivity to the increasing contact angles showing higher slopes in the linear regression line compared with the samples amended with GL (standard errors of the slopes are 0.013 and 0.027 for GL and $\mathrm{CE}$, respectively). Accordingly, the water entry values of samples amended with hydrophobic $\mathrm{CE}$ at different rates showed higher sensitivity to the increasing contact angles showing higher slopes in the linear regression line compared with the samples amended with GL.

However, when the soil was amended with $2 \%$ CE together with $5 \%$ organic manure (CM, GM, and GL) (series II, set B), the relation between contact angle and water entry value did not show a noticeable deviation from that of the soils amended with $5 \%$ organic manure only (series II, set A). About $60 \%$ of the samples (with and without intermixed $2 \% \mathrm{CE}$ ) showed water entry values below $2.5 \mathrm{~cm}$. Results revealed that the addition of 2\% CE did not considerably increase the pressure required for the water entry of the samples amended with $5 \%$ manure. Theoretically, a contact angle of below $90^{\circ}$ is required for the pore capillary forces to pull water into the soil (DeBano, 1981). In the present study, more than $80 \%$ of the samples in series II showed contact angles below $90^{\circ}$, revealing that the addition of manure in the suggested rates would not limit capillary movement of water into the soil.

As shown in Figure 4, the volumetric water content (water retention at $150 \mathrm{~cm}$ suction head) increased with the increasing soil-water contact angles showing moderate to strong positive linear correlations $\left(\mathrm{R}^{2}=0.69-0.80\right)$. The relation between volumetric water content and the soil-water contact angle of 

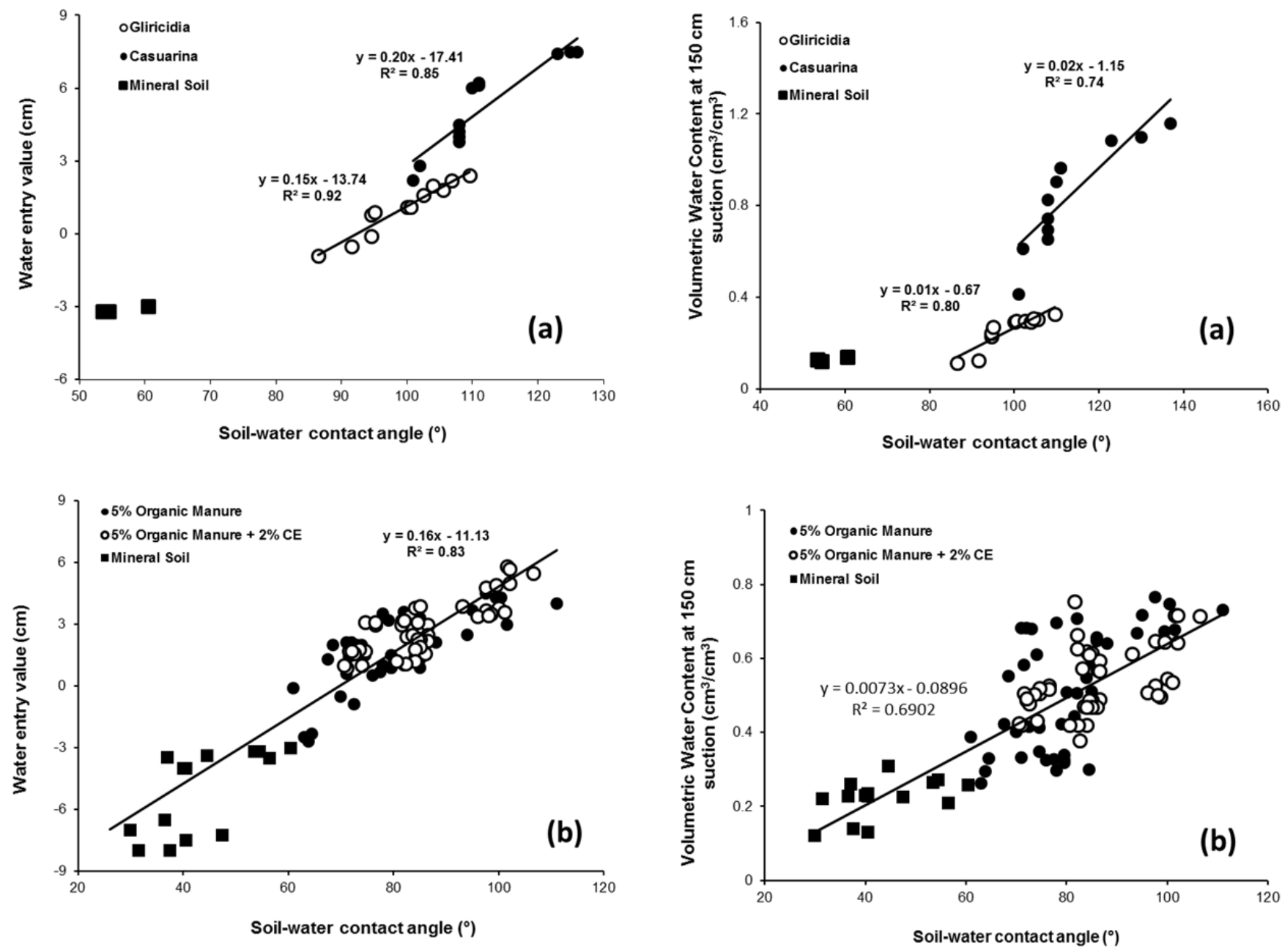

Fig. 3. Relation of the soil-water contact angle to the water entry value of all the samples amended with (a) CE (STD $: 3.06, \mathrm{STD}_{\mathrm{I}}$ : 0.03 ) and GL (STD $: 1.34$, STD $\left._{\mathrm{I}}: 0.01\right)$ (Series I); (b) 5\% organic manure, with and without intermixed $2 \% \mathrm{CE}\left(\mathrm{STD}_{\mathrm{S}}\right.$ : 0.56, $\mathrm{STD}_{\mathrm{I}}$ : 0.01) (Series II). $\mathrm{STD}_{\mathrm{S}}$ : standard error of slope; $\mathrm{STD}_{\mathrm{I}}$ : standard error of intercept.

samples amended with GL and CE at different rates (series I) is shown in Figure 4a. At higher soil-water contact angles $\left(>100^{\circ}\right)$, the CE amended samples showed higher volumetric water content than those amended with GL. At the highest amending rate $(50 \%)$, samples with $\mathrm{CE}$ had $70 \%$ higher volumetric water content than those with GL.

The relation between volumetric water content and soilwater contact angle of soils amended with $5 \%$ organic manure (series II) did not show a considerable difference between those with (set A) and without 2\% CE (set B) (Figure 4b). However, at low soil-water contact angles $\left(<90^{\circ}\right)$, samples mixed with $2 \%$ $\mathrm{CE}$ (set B) showed slightly higher volumetric water contents. Accordingly, it can be suggested that the soils amended with hydrophobic organic manure has high water retention capacity compared with those that are treated with hydrophilic manure. Results revealed that the water retention in tested samples increased with increasing water repellency showing that the addition of $2 \% \mathrm{CE}$ might have favorable impact in retaining more water in soil. Further studies with field experiments are required to find the effect of these amendments on actual water retention in the root zone.

Fig. 4. Relation of the soil-water contact angle to the volumetric water content of all the samples amended with (a) CE (STD $\left.0.376, \mathrm{STD}_{\mathrm{I}}: 0.003\right)$ and $\mathrm{GL}\left(\mathrm{STD}_{\mathrm{S}}: 0.147, \mathrm{STD}_{\mathrm{I}}: 0.0015\right)$ (Series I); (b) 5\% organic manure, with and without intermixed $2 \% \mathrm{CE}$ (STD $: 0.039$, STD I $_{\mathrm{I}}$ 0.0005) (Series II). STD : standard error of slope; $\mathrm{STD}_{\mathrm{I}}$ : standard error of intercept.

There are pieces of evidence available for a considerable decrease in adsorbed water film thickness with increasing contact angle in ideal plane surfaces (Churaev, 1986). However, considering the water content of soils with different contact angles at different water potentials, Bachmann and van der Ploeg (2002) explained that the average water film thickness of water repellent soils seems to be larger compared with ideal plane surfaces. In another point of view, an increase in organic matter content is reported to enhance the water retention in soils at low carbon content (Rawls et al., 2003). Furthermore, additions of hydrophobic humic materials are known to improve the stability of soil aggregates as water repellency is capable of lowering the mechanical breakdown of aggregates by hampering the intra aggregate hydrostatic pressure (Leelamanie et al., 2013). The stabilized aggregates can retain more water among the soil particles increasing the water retention (Goebel et al., 2004a; Piccolo and Mbagwu, 1999).

The pore water in water repellent soils is not uniformly distributed on soil particle surfaces. Still, a considerable uncertainty exists regarding the wetting behavior of dry water repellent soils and its relation to the soil water content. 


\section{CONCLUSIONS}

We explored the effects of water repellency caused by organic amendments on water entry value and water retention of soil. Both water entry value and water retention increased with the increasing water repellency showing positive linear correlations. The samples amended with hydrophobic organic manure at different rates showed higher sensitivity to the increasing water repellency with higher slopes in the linear regression lines compared with the samples amended with hydrophilic organic manure. Mixing of small amount $(2 \%)$ of hydrophobic organic matter with commonly used organic manures slightly increased the soil water repellency. Still, it was not high enough to induce detrimental effects of water repellency and did not cause adverse effects on water entry value and the water retention. On contrary, samples with hydrophobic manure showed increased water retention. As mixing of hydrophobic organic manure with soil is reported to show some benefits such as improving aggregate stability and lowering the depletion rates of organic matter, an improvement of favorable soil hydrophysical properties such as water retention can be considered as an additional advantage. It was clear that intermixing of small quantities of hydrophobic organic manure with organic manures commonly used in Sri Lankan agriculture, would not generate unfavorable impacts on soils. However, different kinds of effects on soil hydrophysical properties may be observed under actual field conditions, and therefore, further experiments with field trials are required for further clarification.

Acknowledgements. We gratefully acknowledge the Faculty of Graduate Studies, University of Ruhuna for providing financial support through a research grant for post graduate studies (MPhil Research Grant 2015/2016).

\section{REFERENCES}

Aye, P.A., Adegun, M.K., 2013. Chemical composition and some functional properties of Moringa, Leucaena and Gliricidia leaf meals. J. Agri. Bio. North Ame., 4, 71-77.

Bachmann, J., van der Ploeg, R.R., 2002. A review on recent developments in soil water retention theory: interfacial tension and temperature effects. J. Plant Nutr. Soil Sci., 165, 4, 468-478.

Bachmann, J., Ellies, A., Hartge, K.H., 2000. Development and application of a new sessile drop contact angle method to assess soil water repellency. J. Hydrol., 231-232, 66-75.

Bauters, T.W.J., Steenhius, T.S., DiCarlo, D.A., Nieber, J.L., Dekker, W., Ritsema, C.J., Parlange, J.Y., Haverkamp, R., 2000. Physics of water repellent soils. J. Hydrol., 231-232, 233-243.

Bisdom, E.B.A., Dekker, L.W., Schoute, J.F.T., 1993. Water repellency of sieve fractions from sandy soils and relationships with organic material and soil structure. Geoderma, 56, 105-118.

Blake, G.R., Hartge, K.H., 1986. Bulk density. In: Klute, A. (Ed.): Methods of Soil Analysis. Part 1. $2^{\text {nd }}$ ed. Agron. Monogr. 9. ASA and SSSA, Madison, WI, pp. 363-375.

Bouyoucos, G.J., 1962. Hydrometer method improved for making particle size analysis of soil. Agronomy Journal, 54, 464-465.

Chenu, C., LeBissonnais, Y., Arrouays, D., 2000. Organic matter influence on clay wettability and soil aggregate stability. Soil Sci. Soc. Am. J., 64, 1479-1486.

Croney, D., Coleman, J.D., 1954. Soil structure in relation to soil suction (pF). J. Soil Sci., 5, 1, 75-84.
Churaev, N.V., 1986. Properties of water layers adjacent to interfaces, In: Croxton, C.A. (Ed.): Fluid Interfacial Phenomena, John Wiley and Sons. pp. 663-738.

DeBano, L.F., 1981. Water repellent soils: a State-of-the Art. General Technical Report PSW-46, Berkeley, CA: USDA Forest Service, Pacific Southwest Forest and Range Experiment Station, pp. 2-4.

de Jonge, L.W., Jacobsen, O.H., Moldrup, P., 1999. Soil water repellency: Effects of water content, temperature and particle size. Soil Sci. Soc. Am. J., 63, 3, 437-442.

Diamantopoulos, E., Durner, W., Reszkowska, A., Bachmann, J., 2013. Effect of soil water repellency on soil hydraulic properties estimated under dynamic conditions. J. Hydrol., 486, 175-186.

Doerr, S.H., Shakesby, R.A., Walsh, R.P.D., 2000. Soil water repellency: Its causes, characteristics and hydro-geo morphological significance. Earth Sci. Rev., 51, 33-65.

Fredlund, D.G., Xing, A., 1994. Equations for the soil water characteristic curves. Can. Geotech. J., 31, 3, 521-532.

Gardner, W.H., 1979. How water moves in the soil? Crops and Soils, 32, 2, 13-18.

Gee, G.W., Bauder, J.W., 1986. Particle size analysis. In: Klute, A. (Ed.): Methods of Soil Analysis. Part 1. Physical and Mineralogical Methods. Agronomy Monograph 9 ( $2^{\text {nd }}$ Edition). Amer. Soc. Agron. Madison, WI, pp. 383-411.

Goebel, M., Bachmann, J., Woche, S.K., Fischer, W.R., 2004a. Soil wettability, aggregate stability, and the decomposition of soil organic matter. Geoderma, 128, 1-2, 80-93.

Goebel, M.O., Bachmann, J., Woche, S.K., Fischer, W.R., Horton, R., 2004b. Water potential and aggregate size effects on contact angle and surface energy. Soil Sci. Soc. Am. J., 68, 2, 383-393.

Good, R.J., 1992. Contact angle, wetting, and adhesion: a critical review. J. Adhesion Sci. Technol., 6, 12, 1269-1302.

Hallett, P.D., 2007. An introduction to soil water repellency. In: Gaskin, R.E. (Ed.): Proc. $8^{\text {th }}$ Int. Symp. on Adjuvants for Agrochem., Hand Multimedia, Christchurch, NZ., 13 p., ISBN 978-0-473-12388-8.

Hole, D.G., Perkins, A.J., Wilson, J.D., Alexander, I.H., Grice, P.V., Evans, A.D., 2005. Does organic farming benefit biodiversity? Bio. Conserv., 122, 1, 113-130.

Karunarathna, A.K., Chhoden, T., Kawamoto, K., Komatsu, T., Moldrup, P., de Jonge, L.W., 2010. Estimating hysteretic soil-water retention curves in hydrophobic soil by a minitensiometer-TDR coil probe. In: Proc. $19^{\text {th }}$ World Congress of Soil Science, Soil Solutions for a Changing World, Brisbane, Australia, pp.58-61, Published on DVD.

Kodesova, R., Nemecek, K., Zigova, A., Nikodem, A., Fer, M., 2015. Using dye tracer for visualizing roots impact on soil structure and soil porous system. Biologia, 70, 11, 14391443.

Leelamanie, D.A.L., 2014. Initial water repellency affected organic matter depletion rates of manure amended soils in Sri Lanka. J. Hydrol. Hydromech., 62, 4, 309-315.

Leelamanie, D.A.L., 2016. Occurrence and distribution of water repellency in size fractionated coastal dune sand in Sri Lanka under Casuarina shelterbelt. Catena, 142, 206-212.

Leelamanie, D.A.L., Karube, J., 2013. Soil-water contact angle as affected by the aqueous electrolyte concentration. Soil Sci. Plant Nutr., 59, 501-508.

Leelamanie, D.A.L., Karube, J., Samarawickrama, U.I., 2013. Stability analysis of aggregates in relation to the hydrophobicity of organic manure for Sri Lankan Red Yellow Podzolic soils. Soil Sci. Plant Nutr., 59, 683-691. 
Leelamanie, D.A.L., Karube, J., Yoshida, A., 2008. Relative humidity effects on contact angle and water drop penetration time of hydrophobized fine sand. Soil Sci. Plant Nutr., 54, 695-700.

Leelemanie, D.A.L., Mapa, R.B., 2015. Alterations in soil aggregate stability of a tropical Ultisol as mediated by changes in land use. Biologia, 70, 11, 1444-1449.

Letey, J., Carrillo, M.L.K., Pang, X.P., 2000. Approaches to characterize the degree of water repellency. J Hydrol., 231232, 61-65.

Lichner, L., Hallett, P.D., Orfanus, T., Czachor, H., Rajkai, K., Sir, M., Tesar, M., 2010. Vegetation impact on the hydrology of an aeolian sandy soil in a continental climate. Ecohydrol., 3, 413-420.

Lichner, L., Holko, L., Zhukova, N., Schacht, K., Rajkai, K., Fodor, N., Sandor, R., 2012. Plants and biological soil crust influence the hydrophysical parameters and water flow in an aeolian sandy soil. J. Hydrol. Hydromech., 60, 4, 309-318.

Madsen, M.D., Petersen, S.L., Fernelius, K.J., Roundy, B.A., Taylor, A.G., Hopkins, B.G., 2012. Influence of soil water repellency on seedling emergence and plant survival in a burned semi-arid woodland. Arid Land Res. Manage., 26, 236-249.

Maia, C.M.B.F., Fukamachi, C.R.B., Cambronero, Y.C., Dedecek, R.A., Mangrich, A.S., Narimoto, K.M., Milori, D.M.B.P., Simoes, M.L., 2011. Hydrophobicity of an entisole under loblolly pine (Pinus taeda) plantation. Bras. J. Forest. Res., 30, 62, 93-99.

McBride, R.A., MacIntosh, E.E., 1984. Soil survey interpretations from water retention data: 1 . Development and validation of a water retention model. Soil Sci. Soc. Am. J., 48, $1338-1343$.

Morel-Seytoux, H.J., Khanji, J., 1974. Derivation of an equation of infiltration. Water Res. Rev., 10, 4, 795-800.

Ouyang, L., Wang, F., Tang, J., Yu, L., Zhang, R., 2013. Effects of biochar amendment on soil aggregates and hydraulic properties. J. Soil Sci. Plant Nutr., 13, 4, 991-1002.

Piccolo, A., Mbagwu, J.S.C., 1999. Role of hydrophobic components of soil organic matter in soil aggregate stability. Soil Sci. Soc. Am. J., 63, 6, 1801-1810.

Pires, L.S., Silva, M.L.N., Curi, N., Leite, F.P., Brito, L.D., 2006. Water erosion in post planting eucalyptus forests at center east region of Minas Gerais State, Brazil. Brasil, 41, 687-695.

Qu, B., Schmitt, J., Chen, Z., Liang, L., McCarthy, J.F., 1994. Adsorption and desorption of natural organic matter on iron oxide: Mechanisms and models. Environ. Sci. Tech., 26, 3846.

Rajkai, K., Toth, B., Barna, G., Hernadi, H., Kocsis, M., Mako, A., 2015. Particle-size and organic matter effects on structure and water retention of soils. Biologia, 70, 11, 14561461 .
Rawls, W.J., Pachepsky, Y.A., Ritchie, J.C., Sobecki, T.M., Bloodworth, H., 2003. Effect of soil organic carbon on soil water retention. Geoderma, 116, 61-76.

Redding, T.E., Devito, K.J., 2006. Particle densities of wetland soils in northern Alberta, Canada. Can. J. Soil. Sci., 86, 5760.

Rodny, M., Lichner, L., Schacht, K., Holko, L., 2015. Depthdependent heterogeneity of water flow in sandy soil under grass. Biologia, 70, 11, 1462-1467.

Rowell, M.J., Coetzee, M.E., 2003.The measurement of low organic matter contents in soils. South African Journal of Plant Soil, 20, 2, 49-53.

Skopp, J.M., 2002. Physical properties of primary particle. In: Warrick, A.W. (Eds.): Soil physics companion, CRC Press, pp. 1-16.

Soil Survey Staff, 2014. Keys to Soil Taxonomy. $12^{\text {th }}$ Ed., United States Department of Agriculture, Natural Resources Conservation Service, pp. 290-303.

Sullivan, L.A., 2006. Soil organic matter, air encapsulation and water-stable aggregation. J. Soil Sci., 41, 3, 529-534.

Vanapalli, S.K., Fredlund, D.G., Pufahl, D.E., 1999. The influence of soil structure and stress history on the soil- water characteristics of a compacted till. Geotechnique, 49, 2, 143-159.

Viville, D., Ambroise, B., Korosec, B., 1986. Variabilite' spatiale des proprietes texturales et hydro dynamiques des 5015 dans le bassin versant du Ringelbach (Vosges, France). [Spatial variability of textural and hydro dynamical properties of soils in the watershed Ringelbach (Vosges, France)]. In: Vogt, H., Slaymaker, O. (Ed.): Erosion Budgets and their Hydrologic Basis. Z. Geomorph. N. F., 60, 21-40. (In French.)

Vogler, E.A., 1998. Structure and reactivity of water at biomaterial surfaces. Adv. Colloid Interface Sci., 74, 69-117.

Wang, Z., Wu, L., Wu, Q.J., 2000. Water-entry value as an alternative indicator of soil water-repellency and wettability. J. Hydrol., 231-232, 76-83.

Ward, P.R., Roper, M.M., Jongepier, R., Micin, S.F., 2015. Impact of crop residue retention and tillage on water infiltration into a water-repellent soil. Biologia, 70, 11, 1480-1484.

Webb, R.W., Stormont, J.C., Stone, M.C., Thomson, B.M., 2014. Characterizing the unsaturated and saturated hydraulic properties of coal combustion by-products in landfills of Northwestern New Mexico. J. Am. Soc. Min. Recla., 3, 1, 70-99.

Weerasinghe, K.D.N., 1989. The rainfall probability analysis of Mapalana and its application to agricultural production of the area. J. National Sci. Coun. Sri Lanka, 17, 2, 173-186.

Received 4 January 2016 Accepted 25 April 2016 